\title{
Genetic Divergence Studies in Marigold (Tagetes erecta)
}

\author{
Sangita Mahanta*, Madhumita Choudhury Talukdar and Pranab Talukdar \\ Department of Horticulture, Assam Agricultural University, Jorhat - 785013 (Assam), India \\ *Corresponding author
}

\section{A B S T R A C T}

\section{Keywords \\ Marigold, varieties, cluster, D2 \\ Analysis, and \\ Genetic Divergence \\ Article Info \\ Accepted: \\ 04 April 2019 \\ Available Online: \\ 10 May 2019}

An experiment was laid out in a randomized block design (RBD) with three replications to evaluate genetic diversity of 12 varieties of marigold using Multivariate genetic divergence analysis (Mahalanobis, 1936). Based on $\mathrm{D}^{2}$ values, all the 12 marigold varieties were grouped into two clusters. Cluster I consisted of 11 varieties, viz., Pusa Narangi Gainda, Pusa Basanti Gainda, Pusa Arpita, Hajo Orange, Mumbai Orange, Hajo Yellow, Sunrise Orange, Hawaii Orange, Calcutta Orange, Calcutta Yellow, Yellow Babuda; while cluster II consisted of only Seracole. The inter-cluster distance between the two clusters I and II was found to be 190.58. The cluster means for most of the characters differed considerably. The intra- cluster distance of cluster I was 42.09 while it was zero for cluster II being with only one variety. The inter-cluster distance being larger than the intra cluster distance suggested wider genetic diversity among the varieties at the two different clusters indicating that crosses may be attempted between the varieties of the cluster I with that of Seracole, the only variety of cluster II to obtain new desirable recombinants in marigold.

\section{Introduction}

Marigold (Tagetes erecta) is one of the most commonly grown commercial flower crops in India. In India, it ranks first among loose flowers followed by chrysanthemum, Jasmine, tuberose and crossandra (Kavitha and Anburani, 2009). Marigold (Tagetes species), a member of family Asteraceae, is the native of Central and South America, especially Mexico. Marigold is extensively used as loose flower, potted plant as well as bedding plant. Besides marigold petals can be used as an additive to poultry feed to improve the pigmentation of the bird's fat, skin and egg yolk due to presence of high carotenoid content in the petals. In order to initiate an effective hybridization programme, selection of parents is crucial as success of crossing is greatly dependent upon the extent of genetic diversity of parents. The genetic diversity study using Mahalanobis's $\mathrm{D}^{2}$ statistic, provides a useful statistical tool for measuring the genetic diversity in a given population which provides clustering of varieties into different groups exhibiting genetic distance between and within groups, thereby facilitating selection of genetically diverse varieties from distant groups as parents in hybridization programme. The resultant hybrids are expected to show high heterosis over the parents for yield and other economic 
characters. The present study was an attempt to investigate the extent of divergence among 12 varieties of marigold grown in Assam using $\mathrm{D}^{2}$ analysis.

\section{Materials and Methods}

The investigation was conducted in the Experimental Field, Department of Horticulture, Assam Agricultural University, Jorhat for two years, during 2015-16 and 2016-17. The experimental material consisted of 12 marigold varieties viz., Seracole, Pusa Narangi Gainda, Pusa Basanti Gainda, Pusa Arpita, Hawaii Orange, Hajo Yellow, Hajo Orange, Calcutta Orange, Calcutta Yellow, Yellow Babuda, Sunrise Orange, Mumbai Orange.The experiment was laid out in randomized block design with three replications. The genetic divergence among the genotypes was quantitatively assessed through Mahalanobis's D $D^{2}$ statistics (1936) and grouping of the genotypes into different clusters was done by using Ward's minimum variance method as described by Rao (1952).

\section{Results and Discussion}

In the present study, based on $\mathrm{D}^{2}$ values, all the twelve varieties were grouped into two clusters (Table 1 and Fig. 1), following the method suggested by Tocher (Rao, 1952), Cluster I was the largest one with 11 varieties while the cluster II possessed only 1 variety. This indicated the presence of appreciable amount of genetic diversity between genotypes of the two clusters. Singh et al., (2002) studied genetic divergence in marigold and grouped 30 accessions into two clusters. The cluster 1 included 29 genotypes, whereas cluster II included only 1 genotype and further concluded that group of the genotypes in cluster 1 showed tight and complete linkage. The present study revealed that the varieties in cluster I are all short day plant whereas the only variety in cluster II viz. Seracole is a day neutral plant which might be the reason that separated the variety in cluster I from the varieties in cluster II. The variety also exhibited clear distinction from all other varieties for most of the characters. The magnitudes of diversity among parents determine the inherent potential of a cross and the selection of a parent based on the genetic divergence would be desirable for creating the maximum variability. Therefore, hybridization programme may be initiated involving the varieties belonging to two different clusters as they are genetically distinct to develop hybrid varieties which can be grown throughout the year because hybrid between two divergent parents gives more heterosis as compared to closely related parents.

\section{Intra and inter-cluster distance}

Table 2 revealed that the inter-cluster distance values were greater than intra-cluster distance values. Among the two clusters, the intracluster distance varied from 0.00 to 42.09. As the cluster II contained only one variety, the intra cluster distance was found to be 0.00 . The inter-cluster distance between clusters I and II was found to be 190.58. The intercluster distance being larger than the intra cluster distance suggested wider genetic diversity among the varieties at the two different clusters.

\section{Cluster means}

The cluster means in respect of 16 characters are presented in Table 3. The data revealed considerable differences among the clusters for most of the characters studied. The maximum mean plant height $(51.43 \mathrm{~cm})$, leaf length $(10.58 \mathrm{~cm})$, leaf breadth $(5.68 \mathrm{~cm})$ and plant spread $(35.86 \mathrm{~cm})$ was observed in cluster-I, while the minimum mean plant height $(44.92 \mathrm{~cm})$, leaf length $(3.77 \mathrm{~cm})$, leaf breadth $(2.36 \mathrm{~cm})$ and plant spread $(34.50 \mathrm{~cm})$ was observed in cluster-II. 
Table.1 Clustering pattern of twelve varieties of marigold

\begin{tabular}{|c|c|c|}
\hline Cluster & $\begin{array}{c}\text { Number of } \\
\text { varieties }\end{array}$ & Variety \\
\hline I & 11 & Pusa Narangi Gainda \\
& & Pusa Basanti Gainda \\
& & PusaArpita \\
& & Hawaii Orange \\
& & Hajo Yellow \\
& & Hajo Orange \\
& & Calcutta Orange \\
& & Calcutta Yellow \\
& & Yellow Babuda \\
& & Sunrise Orange \\
& & Mumbai Orange \\
\hline II & 1 & Seracole \\
\hline
\end{tabular}

Table.2 Intra (bold face) and inter cluster distance among clusters in marigold varieties

\begin{tabular}{|c|c|c|}
\hline Clusters & I & II \\
\hline I & $\mathbf{4 2 . 0 9}$ & 190.58 \\
\hline II & & $\mathbf{0 . 0 0}$ \\
\hline
\end{tabular}

Table.3 Cluster means for different characters

\begin{tabular}{|l|c|c|c|}
\hline \multirow{2}{*}{ Character } & \multicolumn{2}{|c|}{ Clusters } & \multirow{2}{*}{ Over all mean } \\
\cline { 2 - 4 } & I & II & \\
\hline Plant ht (cm) & 51.43 & 44.92 & $\mathbf{4 8 . 1 7}$ \\
\hline No. of branch/plant & 19.24 & 76.12 & $\mathbf{4 7 . 6 8}$ \\
\hline No. of leaves/plant & 54.04 & 240.84 & $\mathbf{1 4 7 . 4 4}$ \\
\hline Leaf length(cm) & 10.58 & 3.77 & $\mathbf{7 . 1 7}$ \\
\hline Leaf breadth (cm) & 5.68 & 2.36 & $\mathbf{4 . 0 2}$ \\
\hline Plant spread (cm) & 35.86 & 34.50 & $\mathbf{3 5 . 1 8}$ \\
\hline Days to bud visibility & 71.54 & 71.18 & $\mathbf{7 1 . 3 6}$ \\
\hline Days to full bloom & 78.13 & 77.62 & $\mathbf{7 7 . 8 7}$ \\
\hline No. of flowers /plant & 50.19 & 99.82 & $\mathbf{7 5 . 0 0}$ \\
\hline Flower diameter (cm) & 5.00 & 5.44 & $\mathbf{5 . 2 2}$ \\
\hline Fresh Wt (g) & 4.85 & 4.72 & $\mathbf{1 8 . 3}$ \\
\hline Self life & 17.23 & 19.37 & $\mathbf{3 . 7 4}$ \\
\hline Loose flower life & 3.09 & 4.4 & $\mathbf{1 5 2 . 0 0}$ \\
\hline No of Ray Florets & 160.24 & 143.77 & $\mathbf{5 4 . 2 5}$ \\
\hline No of Disc florets & 55.02 & 53.48 & $\mathbf{3 5 7 . 7 6}$ \\
\hline Yd per plant (g) & 256.75 & 458.78 & \\
\hline
\end{tabular}


Table.4 Contribution of different characters towards divergence

\begin{tabular}{|l|c|}
\hline Character & Contribution \\
\hline Plant height (cm) & 0.00 \\
\hline $\begin{array}{l}\text { Number of branches per } \\
\text { plant }\end{array}$ & 3.03 \\
\hline Number of leaves per plant & 10.61 \\
\hline Leaf length (cm) & 4.55 \\
\hline Leaf breadth (cm) & 1.52 \\
\hline Plant spread (cm) & 25.76 \\
\hline Days to bud visibility & 13.64 \\
\hline Days to full bloom & 0.00 \\
\hline $\begin{array}{l}\text { Number of flowers per } \\
\text { plant }\end{array}$ & 0.00 \\
\hline Flower diameter (cm) & 1.52 \\
\hline Fresh weight (g) & 4.55 \\
\hline Self life(in days) & 0.00 \\
\hline Loose flower life (in days) & 0.00 \\
\hline Number of ray florets & 19.7 \\
\hline Number of disc florets & 15.15 \\
\hline Yield per plant(g) & 0.00 \\
\hline
\end{tabular}

Fig.1 Dendogram of twelve marigold varieties (Tocher Method; Rao, 1952)

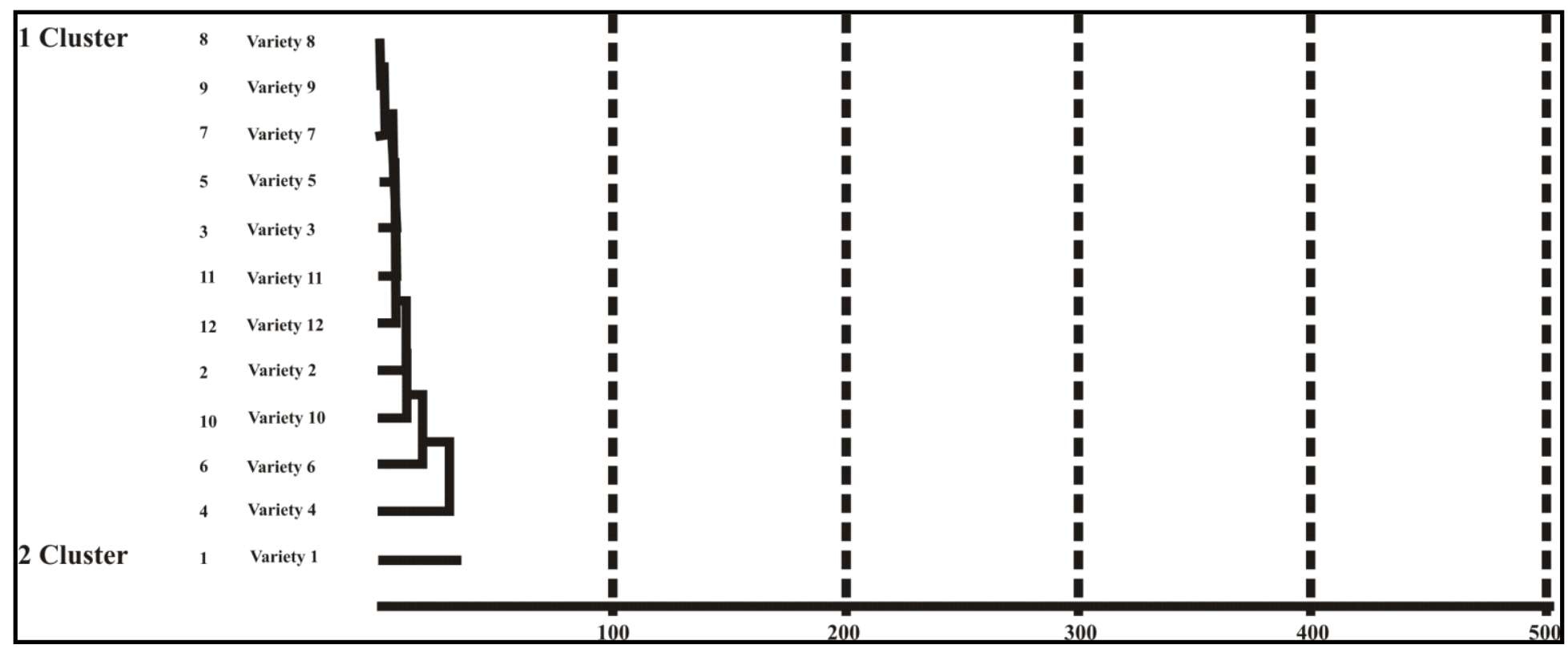

The varieties included in cluster-II showed maximum number of branches per plant (76.12) and number of leaves per plant
(240.84). Days to bud visibility (71.18 days), days to full bloom (77.62 days) were recorded early in Cluster II, while Cluster I recorded 
71.54 days and 78.13 days respectively. Number of flowers per plant (99.82) and flower diameter $(5.44 \mathrm{~cm})$ were recorded highest for cluster II. Fresh weight of flower $(4.85 \mathrm{~g})$, number of ray florets (160.24) and number of disc florets (55.02) were recorded maximum for Cluster I whereas self-life (89.37 days), loose flower life (4.4 days) and yield per plant $(458.78 \mathrm{~g})$ were maximum in Cluster II. The range of means for different characters provided an indication regarding contribution of characters towards divergence.

\section{Contribution of different characters towards divergence}

Contribution of different characters towards divergence is presented in Table 4. Out of 16 characters plant spread was the main contributor towards divergence $(25.76 \%$ contribution). This was followed by number of ray florets $(19.70 \%)$, number of disc florets (15.15\%), days to bud visibility (13.64\%), number of leaves per plant $(10.61 \%)$ and fresh weight $(4.55 \mathrm{~g})$. Based on genetic diversity studies the variety Seracole may be used as one of the parents with Pusa Narangi Gainda and Pusa Basanti Gainda from the other cluster to develop day neutral hybrids. The characters highly contributing towards divergence, viz. plant spread, number of ray florets and disc florets, days to bud visibility, number of leaves per plant and fresh weight deserve due consideration in developing effective marigold hybrid/ improved variety development program.

\section{References}

Kavitha, R. and Anburani, A. (2009). Genetic diversity in African marigold (Tagetes erecta L.) genotypes. Journal of Ornamental Horiculture. 12(3): 198201.

Mahalanobis, P.C. (1936). On the generalized distance in statistic. Proc. Nat. Inst. Sci. Ind. 2: 49-55

Rao, C.R. (1952). Advanced Statistical Methods in Biometric Research. John Wiley and Sons Inc., New York, pp. 45110.

\section{How to cite this article:}

Sangita Mahanta, Madhumita Choudhury Talukdar and Pranab Talukdar. 2019. Genetic Divergence Studies in Marigold (Tagetes erecta). Int.J.Curr.Microbiol.App.Sci. 8(05): 8-12. doi: https://doi.org/10.20546/ijcmas.2019.805.002 